\title{
PENGARUH KEPUASAN KERJA TERHADAP LOYALITAS STAF RECEPTION PADA HOTEL $X$ DI MADIUN JAWA TIMUR
}

\author{
Anwar Basalamah \\ Jurusan Hotel Management, Fakultas Ekonomi dan Komunikasi, BINUS University \\ Jln. K.H. Syahdan No. 9, Palmerah, Jakarta Barat 11480 \\ basalamah.a@gmail.com
}

\begin{abstract}
Reception staff loyalty is much influenced by several factors, one of them is job satisfaction. Employee job satisfaction plays important role in creating employee loyalty. For hoteliers who serve as provider of accommodation services, the demand for the creation of quality human resources is maximum achievement. One of the important section in the front office is receptionist. Today, hoteliers pay very close attention because the employee turnover will certainly affect the consistency of services offered by the hotel. Therefore, the hotel is getting active in increasing the satisfaction of its staff in order to minimize employee turnover especially in a very important role such the receptionist. Although the validity of the relationship between job satisfaction and reception staff loyalty is still an exciting debate, the result of the research conducted in the Hotel $X$ is expected to help increase employee satisfaction in order to create quality of life that will improve labor productivity.
\end{abstract}

Keywords: loyalty, job satisfaction, front office, receptionist, hotel

\begin{abstract}
ABSTRAK
Loyalitas staf resepsionis banyak dipengaruhi oleh beberapa faktor, salah satunya adalah kepuasan kerja. Kepuasan kerja karyawan yang tinggi akan berperan penting dalam penciptaan loyalitas karyawan. Bagi pelaku bisnis hotel yang berfungsi sebagai penyedia jasa akomodasi, tuntutan akan penciptaan sumber daya manusia yang berkualitas merupakan suatu pencapaian yang maksimal. Salah satu bagian penting di front office hotel adalah staf resepsionis. Dewasa ini, pelaku bisnis hotel sangat memerhatikan tingkat pergantian karyawan karena tentunya akan berpengaruh terhadap konsistensi pelayanan yang ditawarkan oleh hotel. Oleh karena itu, hotel semakin aktif dalam meningkatkan kepuasan staf mereka demi meminimalkan turn-over karyawan, khususnya pada bagian yang sangat penting seperti resepsionis. Walaupun keabsahan hubungan antara kepuasan kerja dan loyalitas reception staf masih menjadi perbincangan hangat, hasil penelitian yang dilaksanakan diharapkan membantu Hotel X dalam meningkatkan kepuasan karyawan sehingga tercipta kualitas hidup yang akan meningkatkan produktivitas kerja.
\end{abstract}

Kata kunci: loyalitas, kepuasan kerja, front office, resepsionis, hotel 


\section{PENDAHULUAN}

Semakin berkembangnya jaman, perusahaan-perusahaan menghadapi suatu tantangan dimana persaingan untuk menguasai pasar merupakan suatu hal yang sangat penting bagi kelangsungan suatu perusahaan. Terutama kepuasan karyawan merupakan faktor yang sangat penting, karena karyawan merupakan asset dari perusahaan. Kepuasan karyawan di perusahaan-perusahaan dengan jumlah karyawan lebih dari 500 orang akan lebih rendah dibandingkan dengan kepuasaan karyawan di perusahaan-perusahaan yang jumlah karyawannya kurang dari 100 orang.

Pada dasarnya bertahan atau berhentinya karyawan dari sebuah perusahaan merupakan objektif tentang puas atau tidak puasnya karyawan tersebut. Faktor yang banyak mempengaruhi kepuasan karyawan di sebuah organisasi bisnis sering dihubungkan dengan elemen kompensasi berupa gaji. Sehingga beberapa perusahaan memberikan kompensasi gaji yang relatif tinggi kepada karyawannya untuk membeli kepuasan kepada mereka. Sebenarnya hal ini tentunya tidak mutlak, sebab kepuasan karyawan mempunyai banyak aspek, tidak hanya dipengaruhi oleh faktor materi atau kompensasi secara finansial belaka.

Bagi perusahaan-perusahaan tertentu, bertahannya karyawan mereka umumnya disebabkan oleh faktor-faktor yang bersifat emosional, dibandingkan dikarenakan oleh faktor pendapatan. Faktor emosional tersebut mencakup adanya kepuasan kerja, hubungan baik atasan dengan bawahan, suasana kerja, dan lain sebagainya.

Menurut teori Maslow, kompensasi dan keuntungan yang diperoleh karyawan dari sebuah perusahaan, khususnya yang bersifat material seperti gaji, merupakan dua kebutuhan dasar manusia yang terdapat pada level paling bawah dalam Hirarki Maslow. Sedangkan faktor emosional terhubung dengan tiga kebutuhan dasar Maslow lain di tingkat yang lebih atas. Pada prinsipnya seseorang akan bekerja lebih untuk apa yang mereka minati dan akan bekerja kurang untuk sesuatu yang mereka tidak sukai. Sehingga seseorang yang menyenangi pekerjaanya akan lebih produktif, jika dibandingkan dengan mereka yang hanya menyenangi hasil kompensasi dari pekerjaannya saja.

Pada lingkup pariwisata khusus di industri perhotelan, seseorang karyawan hotel dituntut untuk dapat beradaptasi dengan cepat dan baik terhadap lingkungan kerja, termasuk juga dengan rekan kerjanya. Banyak sekali dijumpai di beberapa hotel dimana karyawannya mengalami kesulitan dalam masa awal kerja, khususnya sulitnya penyesuaian diri terhadap lingkungan hotel yang baru atau asing bagi mereka. Hal ini tentunya wajar bagi karyawan baru, dan kondisi penyesuaian diri yang berat diawal-awal kerja umumnya hanya berlangsung tidak lebih dari satu sampai dua minggu saja.

Berbicara mengenai kesetian atau loyalitas kerja antara satu karyawan dengan karyawan yang lain tentunya memiliki keragaman tingkat loyalitas yang berbeda-beda. Ukuran kepuasan karyawan merupakan langkah awal bagi sebagian perusahaan. Para karyawan merupakan titik temu antara merek perusahaan dan pelanggan. Karyawan yang memiliki kepuasan kerja yang rendah, tentunya akan berakibat terhadap tingat kepuasan pelanggan yang rendah pula. Padahal hidup dan matinya sebuah perusahaan akan sangat bergantung dari kepuasan dan loyalitas pelanggannya. Kepuasan karyawan dapat membantu memaksimalkan profitabilitas perusahaan dalam jangka panjang.

Sehingga merupakan hal yang tepat jika dikatakan bahwa karyawan merupakan aset paling berharga bagi kelangsungan sebuah perusahaan. Karyawan akan menghasilkan kinerja yang maksimal jika mereka memiliki motivasi pribadi yang tinggi. Sebagai seorang manusia, karyawan memiliki sifat-sifat yang mendasar, seperti bisa senang dan bisa pula susah, bisa berpikir rasional dan bisa juga berpikir emosional, punya harga diri, punya visi dan juga cita-cita. Sebagai manusia karyawan juga memiliki kebutuhan. Maslow berpendapat bahwa jenjang kebutuhan manusia sebagai karyawan terdiri 
dari kebutuhan fisiologis, safety needs, social needs, esteem needs, dan self actualization needs. Kebutuhan aktualisasi diri ini tentunya berkaitan dengan keinginan atau kebutuhan manusia untuk diakui orang lain.

\section{Permasalahan Staf Reception Hotel}

Sebagai seorang manusia mereka memiliki kebutuhan untuk mempertahankan hidup mereka dan keluarga mereka. Dimana kepuasan karyawan merupakan kunci penting bagi perusahaan, untuk mencapai sukses. Staf reception merupakan titik temu perusahaan dengan para tamu hotel. Sehingga jika karyawan atau staf reception yang tidak puas sering mengakibatkan pelanggan menjadi tidak puas. Recepsionist hotel merupakan jantung hotel karena kesan pertama dari hotel dapat dilihat pada reseptionis ini.

Adapun tujuan operasional dari penelitian adalah untuk lebih mengetahui sejauhmana pengaruh kepuasan kerja terhadap loyalitas staf reception di Hotel X, Madiun, Jawa Timur.

\section{METODE}

Untuk menjawab permasalahan yang ada maka dilakukan penelitian dengan menggunakan metode penelitian dengan teknik pengumpulan data melalui survey dengan menyebar kuesioner. Populasi penelitian adalah staf hotel. Sampel ditarik dari populasi, hanya sebagian dari populasi menjadi anggota sampel. Tiap anggota populasi mempunyai probabilitas yang sama untuk dimasukkan ke dalam sampel.

Adapun teknik pengumpulan data melalui survei dengan menyebar kuesioner pada staf hotel yang sudah lebih dari 1 tahun bekerja di hotel tersebut. Kueisoner berisi daftar pertanyaan dan daftar pernyataan dengan menggunakan skala Likert.

Penelitian ini merupakan penelitian terapan. Hasil penelitian diharapkan bermanfaat bagi pihak manajemen Hotel X, dalam rangka mengurangi turn-over staf reception. Selain daripada itu, penelitian ini diharapan dapat membantu Hotel $\mathrm{X}$ ini dalam meningkatnya kepuasan karyawan dan kualitas hidup akan meningkatkan produktifitas kerja.

\section{HASIL DAN PEMBAHASAN}

\section{Reception Hotel}

Menurut Agusnawar (2004), kantor depan adalah salah satu kantor departemen di hotel yang secara operasional berhubungan langsung dengan para tamu. Pendapat lain disampaikan oleh Tramoezi (2004), beliau menyimpulkan bahwa Kantor Depan merupakan departemen yang bertanggung jawab, atas penjualan kamar hotel berdasarkan cara yang sistematis melalui reservasi hingga penyerahan kamar kepada tamu hotel dan memberikan pelayanan informasi kepada para tamu selama mereka berada atau menginap dihotel. Berdasarkan pengertian tersebut maka dapat disimpulkan bahwa Front Office merupakan salah satu departemen yang mempunyai peranan sangat penting dalam operasional suatu hotel. Sedangkan seksi bagian dari kantor depan yang sangat krusial adalah reception. Walaupun di era tahun 2000an ini, penggunaan sebutan Reception sendiri mulai digantikan dengan beberapa julukan lain, seperti guest service, front desk dan lain sebagainya. Namun pada dasarnya, bentuk tugas dan tanggung jawabnya adalah sama. 
Menurut Darsono (2001), reception adalah sebuah seksi dari bagian kantor depan yang bertanggung jawab atas semua tamu yang baru datang dan yang sudah tinggal di hotel, serta tamu yang mengakhiri masa inapnya di hotel. Bagian ini memiliki tanggung jawab dalam persiapan sebelum tamu tiba, saat tamu mendaftar di reception, pelayanan penitipan dan pengambilan kunci tamu, pelayanan tamu purdah kamar dan tamu yang berangkat dari hotel, termasuk proses administrasi, arsip, dan laporan-laporan. Agar tamu yang datang ke hotel merasa puas dan menjadi tamu langganan maka petugas receptionist dituntut ramah, rapi, cekatan dan terampil menguasai bahasa asing.

Seperti dibahas sebelumnya, istilah reception mengikuti perkembangan jaman dengan mengadopsi penyebutan jabatan yang lebih bersifat prestige; yaitu front desk clerk, guest service agent, dan lain-lain. Gary dan Jerome (2009) mendefinisikan receptionist sebagai: Receptionist is the term favored outside the United States because elsewhere the function of this position is called reception, not registration. It has a host of duties concentrated in four functions: room sales, guest relations, records and coordination.

Oleh karena itu, dapat disimpulkan bahwa reception merupakan jantung operasional dari suatu hotel. Seluruh aktifitas di hotel akan berawal dari bagian ini dan receptionist-lah yang sering bertemu dengan tamu sehingga petugas atau staf reception hotel dituntut memiliki keramahtamahan, sopan santun dan pengetahuan produk dan service yang tinggi serta mampu menarik konsumen.

\section{Kepuasan Karyawan}

Krisis manajemen yang terjadi di Indonesia pada tahun 1998 memberikan dampak yang cukup besar terhadap karyawan perusahaan, khususnya dalam pemberian kompensasi atau gaji tertunda. Sebagai seorang manusia mereka memiliki kebutuhan untuk mempertahankan hidup mereka dan keluarga mereka. Di mana Kepuasan karyawan merupakan kunci penting bagi perusahaan, untuk mencapai sukses.

Meningkatnya kepuasan karyawan dan kualitas hidup akan meningkatkan produktifitas kerja. Resepsionis merupakan titik temu perusahaan dengan para pelanggan. Sehingga jika karyawan atau staf resepsion yang tidak puas sering mengakibatkan pelanggan menjadi tidak puas. Resepsionis merupakan jantung Hotel karena kesan pertama dari hotel dapat dilihat pada reseptionis ini. Berdasarkan uraian diatas, maka identifikasi masalahnya adalah belum diketahuinya pengaruh kepuasan kerja terhadap loyalitas reseptionis pada bisnis perhotelan.

\section{Kepuasan Kerja}

Menurut Handoko (2001), kepuasan kerja adalah keadaan emosional yang menyenangkan atau tidak menyenangkan dengan mana para karyawan memandang pekerjaan mereka. Pendapat yang hampir menyerupai datang pula dari Danish dan Usman (2010) yang mengartikan kepuasan kerja atau job satisfaction sebagai: Job satisfaction is the enjoyable and emotional state resulting from the evaluation of one's job or job experiences; the employee feels fulfillment and pride in achieving the business's goals.

Namun Garcez (2006) memiliki pandangan yang lebih dalam, beliau mendefinisikannya sebagai: Job satisfaction occurs when someone feels he/she has proficiency, value, and is worthy of recognition.

Menurut Hasibuan (2005), kepuasan kerja adalah sikap emosional yang menyenangkan dan mencintai pekerjaannya. Di mana sikap ini dicerminkan oleh kedisiplinan, moral dan prestasi kerja. 
Berdasarkan pendapat-pendapat tersebut, dapat ditarik simpulan bahwa kepuasan kerja adalah suatu perasaan yang menyokong atau tidak menyokong diri pegawai yang berhubungan dengan pekerjaannya maupun dengan kondisi dirinya. Perasaan yang berhubungan dengan pekerjaannya melibatkan aspek-aspek seperti upah atau gaji yang diterima, kesempatan pengembangan karir, hubungan dengan pegawai lainnya, penempatan kerja, jenis pekerjaan, struktur organisasi perusahaan, mutu pengawasan, sedangkan perasaan yang berhubungan dengan dirinya, antara lain umur, kondisi kesehatan, kemampuan, pendidikan. Pegawai akan merasa puas dalam bekerja apabila aspek-aspek pekerjaan dan aspek-aspek dirinya menyokong dan sebaliknya jika aspek-aspek tersebut tidak menyokong, pegawai akan merasa tidak puas.

Menurut seorang ahli Psikolog Frederick Herzberg, ada 2 faktor kepuasan kerja, antara lain (Robbins, 2003), yaitu: (1) faktor motivasi, peluang promosi, peluang pertumbuhan pribadi, pengenalan, tanggung jawab, prestasi; dan (2) faktor hygiene, kebijakan perusahaan dan administrasi, pengawasan, hubungan antar pribadi, kondisi kerja, gaji.

Jadi, menurut Herzberg, faktor-faktor yang menuju kepuasan kerja terpisah dengan faktorfaktor yang menuju ketidakpuasan kerja. Sehingga para manajer berusaha untuk mengeliminasi faktorfaktor yang menyebabkan ketidakpuasan kerja dapat membawa suasana kedamaian, tetapi tidak selalu menimbulkan motivasi. Sebagai hasil karakteristik serupa itu seperti kebijakan dan administrasi perusahaan, pengawasan, hubungan antar pribadi, kondisi kerja dan gaji telah dikelompokkan oleh Herzberg sebagai faktor hygiene. Jika faktor ini memenuhi persyaratan, para karyawan tidak akan merasa tidak puas, tetapi tidak juga merasa puas. Jika ingin memotivasi para karyawan terhadap pekerjaannya, Herzberg menyarankan pengutamaan Peluang promosi, Peluang pertumbuhan pribadi, Pengenalan, Tanggung jawab, Prestasi. Karakteristik inilah yang membuat para karyawan merasa memperoleh penghargaan intrinsik. Adapun gambar perbandingan kepuasan dan ketidak puasan menurut Herzberg.

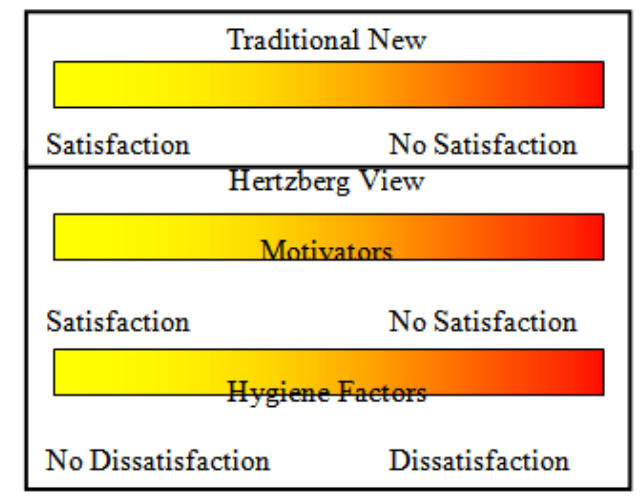

Gambar 1 Contrasting view of satisfaction and dissatisfaction

Ketidakpuasan karyawan dapat dinyatakan dengan hal berikut sebagai contoh, berhenti/meninggalkan, karyawan dapat mengeluh, tak patuh, mencuri properti/milik organisatoris, atau melalaikan bagian dari tanggung jawab kerja mereka.

Empat respons berbeda dengan satu sama lain sepanjang dua dimensi, yaitu bersifat membangun/aktif dan bersifat merusak/pasif mereka digambarkan sebagai mengikuti, yaitu: (1) jalan keluar (exit), perilaku mengarahkan ke arah meninggalkan organisasi itu, termasuk mencari suatu posisi baru seperti halnya yang berhenti; (2) suara (voice), dengan aktif dan secara konstruktif mencoba untuk meningkatkan kondisi, termasuk mengusulkan peningkatan, mendiskusikan 
permasalahan dengan atasan, dan beberapa format aktivitas perserikatan; (3) kesetiaan (loyalty), dengan pasif tetapi optimistically menantikan kondisikondisi untuk meningkatkan, mencakup menjamin organisasi itu di wajah kritik eksternal dan mempercayai organisasi itu dan manajemennya, untuk "lakukan hal yang benar"; dan (4) pengabaian (neglect), dengan pasif membiarkan kondisikondisi untuk bertambah buruk, mencakup larut malam atau ketidakhadiran kronis, usaha yang dikurangi, dan meningkat laju.

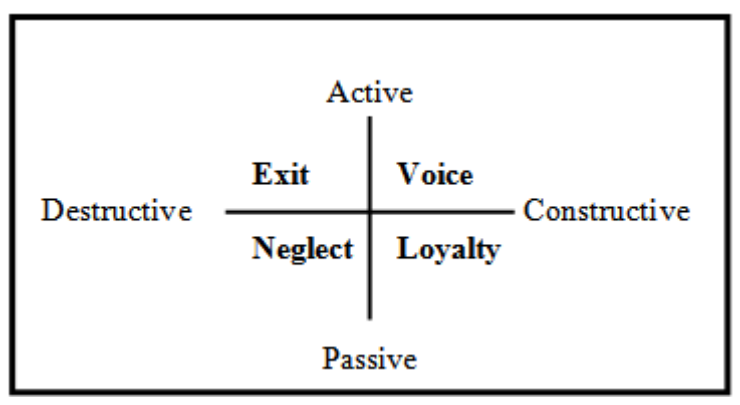

Gambar 2 Responses to job dissatisfaction

Adapun faktor-faktor yang mempengaruhi kepuasan kerja, yaitu yang ada pada diri pegawai dan faktor pekerjaannya (Mangkunegara, 2005). Faktor pegawai, yaitu kecerdasan, kecakapan khusus, umur, jenis kelamin, kondisi fisik, pendidikan, pengalaman kerja, masa kerja, kepribadian, emosi, cara berpikir, persepsi, dan sikap kerja. Faktor pekerjaan, yaitu pekerjaan, struktur organisasi, pangkat atau golongan, mutu pengawasan, jaminan finansial, kesempatan promosi jabatan, interaksi sosial, dan hubungan kerja.

\section{Loyalitas Kerja}

Loyalty significantly strengthens employee intent to stay in the same hotel and their willingness recommends a hotel brand to other (Barsky \& Nash, 2002). Artinya kesetiaan diartikan kekuatan yang dimiliki karyawan yang bermaksud untuk mempertahankan pekerjaan yang sama, dan kesediaan karyawan tersebut untuk memperkenalkan hotel kepada pihak lain. Menurut Baloglu (2002), loyalitas adalah sikap benar-benar setia dari anggota suatu perusahaan kepada perusahaan tempatnya bekerja, mereka bersikap seolah-olah setia karena ingin mendapatkan keuntungan.

Berdasarkan beberapa pendapat diatas maka dapat disimpulkan loyalitas adalah sikap seorang karyawan yang selalu setia terhadap hotel tempatnya bekerja. Kesetiaan ini timbul dalam diri karyawan tanpa mengharapkan akan mendapatkan imbalan dari hasil sikap setia tersebut.

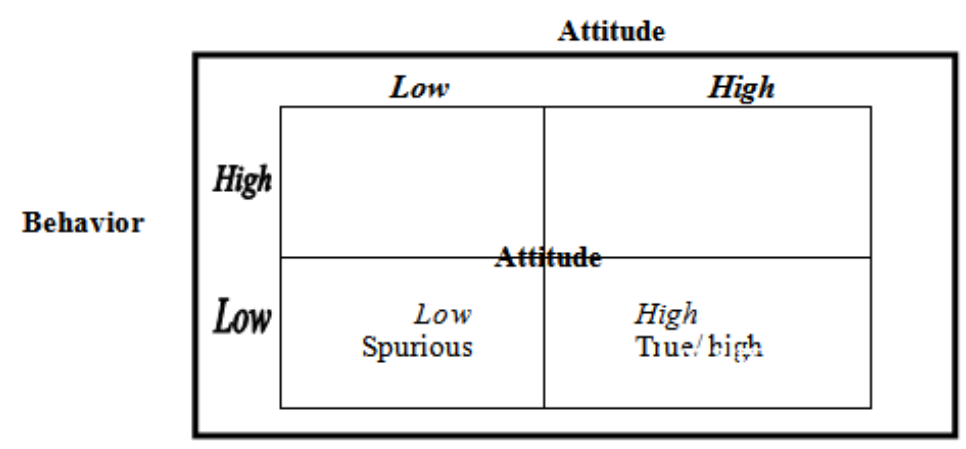

Gambar 3 Tingkat kesetiaan 
Menurut Baloglu (2002) tingkat kesetiaan karyawan diklasifikasikan menjadi 4 bagian yaitu: (1) High Loyalty, karyawan yang menunjukan sikap atau pendirian setia yang kuat dan akan selalu berpihak pada hotel tempatnya bekerja. Karyawan akan selalu mempertahankan pekerjaannya pada satu hotel saja dan tidak akan sedikitpun tertarik pada penawaran kerja di tempat atau hotel lain; (2) Latent Loyalty, karyawan yang menyimpan sikap atau pendirian setia yang kuat terhadap hotel tempatnya bekerja. Rendahnya nilai kesetiaan karyawan tersebut terjadi karena karyawan tidak memiliki alasan yang cukup untuk menambah nilai kesetiaan itu; (3) Spurious Loyalty, sikap kesetiaan seperti ini ditandai dengan karyawan yang memutuskan untuk tetap bertahan bekerja walaupun sebenarnya dia tidak ingin bertahan bekerja di hotel tersebut; (4) Low Loyalty, ditunjukkan dengan lemahnya pendirian atau sikap setia terhadap hotel dan juga lemahnya sikap memikat tempat bekerja.

Faktor-faktor yang dapat membuat karyawan tetap bekerja (Greenberg \& Baron, 2003), yaitu: (1) Keinginan untuk melanjutkan, karena adanya keinginan untuk dapat melanjutkan ke jenjang atau level yang lebih tinggi maka karyawan tersebut akan tetap bekerja agar apa yang diinginkan dapat terpenuhi; (2) keinginan untuk mencapai tujuan, karena adanya tujuan yang ingin di capai oleh setiap karyawan maka karyawan tersebut akan tetap bertahan untuk bekerja sehingga apa yang telah di tetapkan sebelumnya dapat tercapai; (3) keinginan karena kewajiban, karyawan akan tetap bekerja karena adanya suatu kewajiban yang dimiliki oleh setiap karyawan kepada perusahaan tempatnya bekerja sehingga karyawan tersebut tetap bertahan di tempat kerjanya.

Adapun faktor lingkungan kerja yang dapat mempengaruhi karyawan untuk tetap bekerja (Greenberg \& Baron, 2003), yaitu dimensi sociability dan solidarity. The socialibility dimension merupakan batasan ukuran hubungan karyawan yang satu dengan yang lainnya di dalam suatu perusahaan. Keramah tamahan dalam pergaulan akan membantu memperkenalkan kreativitas, karena, akan memberikan semangat orang untuk bekerjasama dalam suatu tim dan berbagi informasi serta akan membuat mereka bersikap terbuka terhadap kritik dan saran serta ide-ide baru. Akan tetapi dalam sisi negatife keramah tamahan seseorang dalam bergaul dapat menyebabkan adanya kelompok yang kurang atau tidak formal pada saat bekerja. Hal akan sangat mempengaruhi dalam proses pengambilan keputusan.

The solidarity dimension fokus pada bagaimana seorang karyawan dapat berbagi dengan karyawan yang lainnya tentang pengetahuan dan tujuan dari perusahaan tempat mereka bekerja. Akan tetapi seringkali terjadi para karyawan bekerjasama tetapi mereka jarang mau berbagi.

\section{Kerangka Pemikiran}

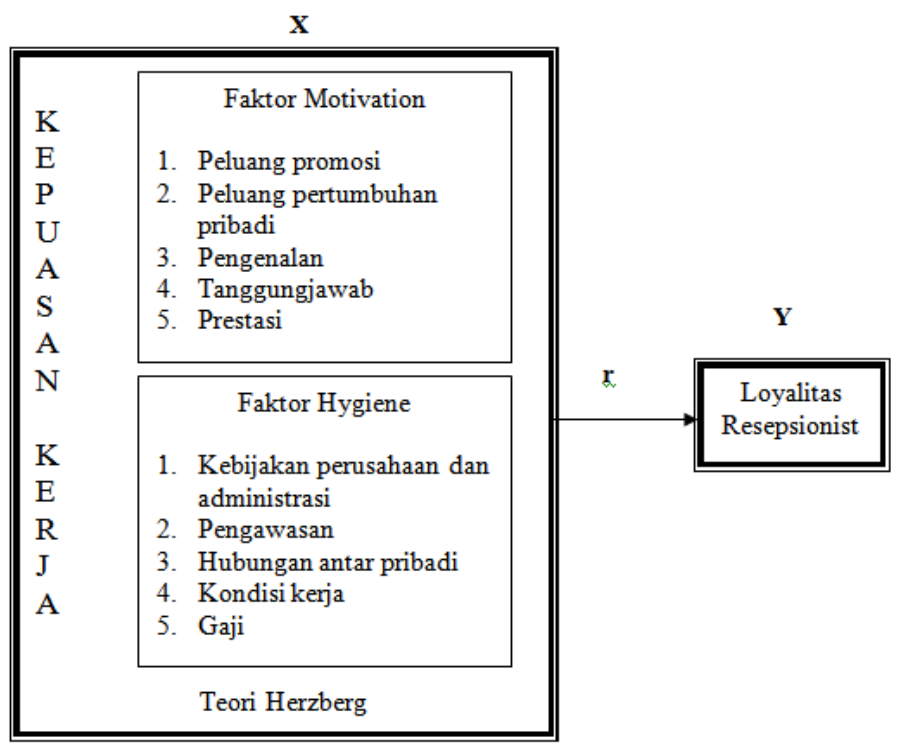

Gambar 4 Kerangka pemikiran 
Berdasarkan kerangka pemikiran pada Gambar 4, maka dapat ditarik simpulan bahwa jika kepuasan kerja yang berhubungan dengan faktor instrinsik dan faktor ekstrinsik dapat terpenuhi dengan baik maka maka resepsionis akan memiliki loyalitas pada pekerjaannya. Dimana loyalitas dari resepsionis dapat dilihat dari minat resepsionis terhadap pekerjaan yang dilakukan, suasana lingkungan kerja dan tempat karyawan bekerja serta waktu (kehadiran serta ketepatan waktu dalam bekerja).

\section{PENUTUP}

Berdasarkan pembahasan tersebut, tingkat kepuasan kerja pada staf reception hotel akan dapat berkesinambungan dengan loyalitas kerjanya. Kepuasan kerja dapat terpenuhi dengan baik, jika manajemen hotel memiliki momitmen bersama dengan staf reception untuk memenuhi kebutuhan satu sama lainnya. Sehingga diharapkan hal tersebut berdampak positif terhadap ketertarikan sikap dan simpati karyawan yang berada dalam nauangan departmen Front Office ini, untuk bertahan atau loyal kepada hotel. Dalam usaha mencapai kepuasan kerja sendiri, terdapat 2 (dua) faktor penting yang menentukannya, yaitu faktor motivasi dan hygiene. Kedua faktor ini tentunya sangat berperan penting untuk menciptakan kepuasan kerja karyawan, dalam hal adalah staf reception hotel. Sehingga dengan tercapainya kepuasan kerja tersebut, maka diharapkan terbentuk proses loyalitas kerja yang meningkat. Bagi staf reception hotel yang memiliki mobilitas kerja serta tuntutan tugas dan tanggung jawab yang kompleks, bentuk kepuasan kerja akan sangat membantu dalam proses pembentukan loyalitas pada hotel yang dinaungi oleh karyawan tertentu. Bentuk-bentuk penghargaan kepada karyawan reception, tentunya akan lebih membantu dalam proses pembentukan loyalitas pada karyawan. Adanya peningkatan untuk lebih menghargai hasil kerja staf reception hotel akan memotivasi mereka untuk bekerja lebih baik dan maksimal kepada perusahaan. Hal yang perlu ditanamkan bersama adalah perlu adanya perhatian manajemen hotel kepada staf-stafnya, khususnya staf yang memiliki intensitas pertemuan dengan klien yang tinggi, dalam hal ini seperti staf reception. Karyawan merupakan aset yang paling berharga bagi perusahaan, apalagi bagi pelaku usaha berbasis pelayanan.

\section{DAFTAR PUSTAKA}

Agusnawar. (2004). Resepsionis hotel. Jakarta: Gramedia Pustaka Utama.

Barsky, J., \& Nash, L. (2002). Evoking emotion: Affective keys to hotel loyalty. Cornell Hotel and Restaurant Administration Quarterly, 43(1).

Danish, R., \& Usman, A. (2010). Impact of reward and recognition on job satisfaction and motivation: An empirical study from Pakistan. International Journal of Business and Management, 5(2), 195-167.

Garcez, C. (2006). Job satisfaction: The challenges transformed organizations face. miscellaneous. Diakses pada 13 Maret, 2012, dari: http://aplawrence.com/Misc/job_satisfaction.html

Greenberg, R. A., \& Baron, R. A. (2003). Behavior in organizations. Upper Saddle River, NJ: Prentice-Hall.

Hasibuan, M. S. P. (2005). Organisasi dan motivasi dasar peningkatan produksivitas. Jakarta: Bumi Aksara. 
Mangkunegara, A. P. (2005). Manajemen sumber daya manusia perusahaan. Bandung: Remaja Rosdakarya.

Robbins, S. P. (2003). Organizational behaviour. New York: Prentice Hall. 